\title{
Some: an ode to the partitive article
}

Some burn-outs on asphalt stretch outside trig tables

Some galahs refuse to toe the line

Some solar cells gather waving lines of morphemes

Some striated pardalotes nidify just now, some shortly

Some spray booms disassociate, haze painted button quail

Some crop dusters plague the guy waving from his rooftop

Some bush bashers patiently tend some crops-in-the-bush you stay away from if you don't want to be shot

Some windmills shake down, rung on rung of saline accumulation

Some hubs on mallees mark driveways

Some samphire is salt bush in some necks of the clear-fell

Some wedgetail eagles harried by crows stay high above pasture

Some laterite conduits are County Peak

Some casuarinas are melaleucas are grevilleas are hakeas are acacias are eucalypts if you forget your guide book

Some poddy-dodgers are dodgers of law-makers and indulgers of flesh intakers

Some sandhi are a(n) handy way of vowelling a wheat harvester

Some intermediaries focus specific causes for a decline in yellow skink numbers

Some wattles hold back flowering (sometimes)

Some farmers drive past three times in case they've missed catching you

Some lives are lost on crossroads

Some parishioners visit other people's churches, temples, mosques...

Some prayers connect and others don't, all get played back, are held to account

Some red-capped robins rip into our dark spots

and make light of them

Some polluted places are so beautiful

they make you weep buckets... 